\title{
Wine Tasting Discourse: Traditional Knowledge, and Practice
}

\author{
Kilien Stengel1,2,3, Angelica-Helena Marinescu ${ }^{4}$ \\ ${ }^{1}$ Rabelais University, European Institute of Food Culture and History, Tours, France \\ ${ }^{2}$ Laboratory CIMEOS, University of Burgundy, Dijon, France \\ ${ }^{3}$ Laboratory PRIM, University of Tours, Tours, France \\ ${ }^{4}$ University of Bucharest, Bucharest, Romania \\ Email:kilien.stengel@univ-tours.fr, angelica.marinescu@yahoo.ro
}

Received 11 April 2016; accepted 20 May 2016; published 23 May 2016

Copyright (C) 2016 by authors and Scientific Research Publishing Inc.

This work is licensed under the Creative Commons Attribution International License (CC BY). http://creativecommons.org/licenses/by/4.0/

(c) $\underset{\mathrm{EY}}{0}$ Open Access

\section{Abstract}

Traditions, brotherhoods, wines of terroir, vintage wines...so many expressions that, beyond the numerical value, compose the wine tasting speech, in France as well as in Romania, among others. The rising of awareness concerning traditions and heritage notions has largely evolved during the XXth century, spanning from the vineyard as a field for the theatricality of the brotherhoods to the considerations given to rites and customs, as well as to wine-tasting, till the larger social context. The taste related cultural discourse or argumentation plays a major role, from a pragmatic as well as cognitive viewpoint, within the wine tasting process, in order to represent a product or conceive an advertising. Wine provides experience and subjectivity in the frame of a taste-related simulation, always new, always personal. Thus, wine language is often very different from subjective perception, which is correlated to sensorial memories resulted from past tasting experiences or situations. How to communicate about wine, from different perspectives? Or how to pass on discoursive references and representations of the good wine? These questions send to the subjectivity of wine quality, to the connection that we might have with the product, as well as to wine's cultural imaginary, in a multidisciplinary and intercultural perspective. In the frame of wine tasting theatricality, taste is subjective and each person's judgement concerning wine taste is in accordance to his or her own "oenologism": meaning its identity specter as a taster. The tasting procedure, beyond being a savoir-faire, it's an incorporation experience which shares a part of one's own identity. Thus, the meanings and values attached to the notion of wine desire vary depending upon the significations given to the representations of "good" wine, and are illustrated by a personal speech reference.

\section{Keywords}

Transmission, Vocabulary, Wine-Tasting, Interculturality, Multidiscliplinarity 


\section{Introduction}

Vineyard is one of the components of the French cultural and heritage landscape, as well as Romanian, and introduces a second degree approach, that of wine making and tasting knowledge (savoir-faire, savoir-boire) as presentative for the territorial identity.

One of the common values to these two kinds of representation of folklore type is the appropriation of the heritage value recognised as exceptional-an individual appropriation through the mediation of perception, touching, smell and taste, a collective appropriation throughout the recognition of an identity and territorial community.

But do the wine-related heritage argumentations have influence on the taste or cultural perceptions? Aren't they the actual supports for a quality discourse, often imaginary and visually constructed in the detriment of the experience quality? Furthermore, what sensorial references to consider when the individual perception experience can be neither standardized by a generic terminology around the notion of "quality", neither theoretically transmitted?

Our approach is thus observing the methodologies concerning wine and vine speech, in the folklore frame of its transmission (tasting evening, brotherhood enthroning evening,...), based on its restitution through significant experiences, and with a heterogeneous documenting in order to highlight the interdisciplinarity of the thematics and of the participants in this research modelling.

The registration of the gourmet meal of the French people to the UNESCO Representative List of the Intangible Cultural Heritage of Humanity (2010), where wine tasting is included, reflects once again the desire to promote regional products of winemaking, in order to include them in a formal and cultural heritage framework.

Thus, the wine as a "social element" signifies to a taster ${ }^{1}$ its affiliation to a chain of relations linked to the pleasure of tasting. The wine as a "cultural element" represents the totality of intellectual resources based on or related to this topic. The wine as a "symbolic element" signifies the power of recognition that the individual can take advantage of, thanks to his arguments and to tasting rites.

These regular processes of (re)signification of the wine representation rely on the conceptualizations of tasting that we will discuss in the first part of this article. We will further approach the identity and contextual discourses that offer the raw material to the commercial arguments, in the second and third chapter. In the end of the article we will refer to the identity of the taster, the temporality and the related transmission tools. In fact, we will approach from this point of view the transmission of the wine interpretations by means of cultural contribution, in a multidisciplinary perspective.

In terms of methodology, we could have used in this study the etymological approach, borrowing information about the origin of terminologies and concepts from different linguistic [1] and lexicological [2] disciplines. Yet, we decided to orient our research towards the discourse analysis, in an interdisciplinary perspective, between anthropology and communication, starting from the observation that wine and wine tasting and its argumentations involve identity and (multi) cultural approaches, taking into consideration two different cultural and social spaces, such as France and Romania.

\section{The Conceptualization of Well-Drinking}

As a form of paradox related to wine tasting, where we can measure "reason" and "passion", the consumers who developed an equanimity in their relationship with the wine are divided in two groups: on one side, the adepts of the academic or professional process of wine tasting [3], and, on the other side, the hedonists. The meanings and the values attributed to the concept of desire for wine vary according to the consideration given to the representations of "good" wine. Whether these considerations are moral, religious or involving heritage and its transmission, they appear as choice criteria. These criteria define the representations of wine from each person's perspective, in relationship to a high quality tasting process. They also create a "discrepancy between norms and practices" [4], a distance between what the individual thinks to be "good", what he or she drinks and eventually the manner they consume it on a daily basis.

The sensory analysis focuses on attention, while it stimulates the senses (sight, hearing, smell, touch, taste) and opens the way to hedonism using the haptic interface defining the wine in terms of the subjectivity of the

\footnotetext{
“"Taster” is a term which appeared during the French Revolution (Frey, (1793) Journal de la Montagne, nov. 1793). Also frequently used in that era by chemists (Deveux N. “Analyse des vins frelatés”, dans Journal de la Société des Pharmaciens de Paris ou recueil d'observations de chimie et de pharmacie, Chez Bernard, p.194).
} 
product. Just like communication and information sciences, the wine speech was approached consequently as a "'social science', a 'meta-science', an 'inter-science' (multidisciplinary), a 'postmodern science', an 'interface science', a 'superior science', a 'rhetorical science', a 'knowledge science' or a 'nomad science'” [5]. Whilst the analytical phase concentrates on memorizing and associates the identification of the tastes and flavors to the culture or the wine typologies [6], the pleasure of expression itself, during the hedonistic tasting, expresses by the means of the vocabulary adapted to the sensations and to the remembrance.

Keeping in my memory the intense pleasure that I had experienced while drinking a good wine will not only make me happy when I remember it, but will also make me consider tasting it again. [7]

\section{Oenology: From an Amateur's Discourse on Identity to the Sixth Sense of the Professional Taster}

What is the meaning of "wine tasting”? In a world where the food supply doesn't respond to the general expectations and to all the taste sensations, what does actually "tasting the wine" mean, if not an offering to our mouth and to our spirit, intuition or rejection? It may as well happen that we don't feel the interest to taste the wine, because we are no longer able to observe neither the authenticity nor the impression which link the wine to our existence. When the wine is no longer attracting the attention of the senses, the senses lose their basic meaning. And when our senses are dying, absurdity springs. Our taste and smell can sometimes deceive us. During a wine tasting we can be deluded in our attempt, to the eyes of the educated amateurs, in the identification of the ingredient or of the mysterious flavor. Thus, we believe that we can distinguish between what we taste and recognize and what we smell. But it is sometimes a mistake from a professional point of view, as the normative reality is not always present in what our senses tell us or in the modeling of the tasting procedure. Because there is always more than one truth in each reality and "modeling is a production, starting from the reality, of a formalized description, that can go so far as to reveal the formula that reflects the reality" [8].

For example, the acidity or the sweetness of a wine does not have the same level of identification for each person. Some tasters will be able to estimate the typical acidity level for a Chablis only after a certain degree of experience, always different from that of others tasters. The same ascertainment can be made for tannicity, astringency, suavity, minerality. "While taste is polysemous, tasting would like a sole definition. A paradox that professionals have to solve in order to validate their formation and give credibility to their competences" [9].

We will have to admit that the first contact with the analytical tasting, and in fact with the wine, has sometimes disastrous effects. The apprentice taster may have the impression that he is unable of distinguishing among the different flavors and that his senses are unreliable. He or she sometimes abandons the apprenticeship for becoming a sommelier or a genuine taster, confining himself or herself to the simple act of drinking without improving or developing his wine argumentation. But the concern is that the senses, under the yoke of the discursive standard, can only make us distinguish one reality. Yet the flavor, the bouquet and their real definitions may vary for each and every one of us. Everyone understands what he wants to understand and defines as non-existent what he is unable to define. So what we experience while trying to comply with a social prototype cannot reveal the hypothesis of a flavor contrary to the expectations of the "caste" of educated amateurs of wine. Although our senses reveal to us a different reality in terms of taste and smell, we may often choose to remain silent rather than being considered ignorant.

Thus, if there are people playing with the art of tasting, the wine speech is nevertheless nothing more than a simple medley of olfactory notes. Even if some people enjoy a sad or dark wine, all wine argumentation will not have to be sad and dark. But will the wine discourse then be a cultural light in the darkness of the night? Generally speaking, as the wine, when used abusively, can dehumanize, aren't the committed discourses of wineproducers in search of an yet subjective quality, the sign that wine is not so devoid of meaning?

Thus, if there are people who single out in the art of tasting and consider themselves as real tasters (wine waiters, wine brokers, fraternity members, experts and examiners for taste competitions, authors of wine guides...), it is still true that each and every of them estimates its expertise in accordance to the finality of the act (of tasting). The real taster will only be singular in relation to the object of his research: research for a normalized typicality for the organization of a contest, research of originality in order to write a wine guide, research for "wine poetry" or at least a cultural argumentation for wine selling in a restaurant. "This revealed truth stands for a non-biased, wiser position. In fact, what redeems wine value when it seems to have been corrupted or neglected by weakness, laziness or interest-based-logic, is always the powerful recurrence of the imaginary, the sociality 
and flavor and moments of sharing, the power of emotions and the sensations that we seek for. Wine as translated into language, into sharing, into heritage. Words, moments, emotions that appear depending on the speech need. That is how wine takes shape into daily life or for exceptional events" [10].

We should always keep in mind the idea that wine gives a meaning to the lives of some of us, only if some people give a meaning to wine by transforming it and learning about it. Tasting represents a relationship of man to wine and of wine to man, "a communication from consciousness to consciousness, furthermore, from a living creature to another living creature or, as the pragmatists say it, from subject to subject" [11].

Human life has no meaning without a culture concerning "what to incorporate?" and "how to incorporate?". Wine culture, seen as an Art of drinking, is thus meaningful only if we envisage it with humanity, consciousness and ethics.

Obviously, it's a matter of consciousness. Thus my faith in the intimate communication between the two natures, or at the very least in the intervention of the soul on the body, comes from my own awareness. [12]

Isn't the most subtle connection to the wine consisting of valuing it by words? Tasting and knowing to analyze what we drink, "is good" [13], "is healthy" [14], but it is best to debate either using suitable terms, or your own words and sincerity.

Furthermore, tasting for the sake of tasting is also limiting. Definitely, whoever admits making tasting experience admits being open to novelty, to originality as well as to diversity, in a provided framework [15]. But whoever admits making a tasting experience in order only to make experiences, also admits only repeating the same procedure, consisting of collecting tastings [16]. This has nothing original in itself, as multiplying the sensory information and the tasting details about the product does only provide us with information and details, without teaching us how to use them during the meal or how to pass them on to other persons or to other generations.

Would the tasting experience be really able to bring us something special, if not to "become gradually, through experience, more and more skillful in the management of these face to face interactions" [17]? For example, an exceptionally good description of a particular wine can make us experience a temporary sensation, as the one related to a path in a wet underwood after an autumn rain. This sensation starts spreading in our imagination, making us connect with nature. It will become in our spirit kind of a pre-requisite and will give place to further estimations. Proust (1871-1922) shared with us his experience caused by a little muffin [18] soaked in a small cup of linden tea. He got the feeling of experiencing that precise muffin inside of him. As he felt this sensation spreading, he became aware of the secret of the tasting recollection that managed to open the doors of the creativity for him. Although the savored sensation is ephemeral, it allows us to enjoy the culinary moment which goes by so quickly. In a unique tasting multisided experience, would the muffin, that is so well-known by everyone, have a temporary hidden flavor?

Would this taste aspect, that will first glimpse in our imagination, then change into a belief, be just another side among many others that are unknown to our taste palate and also to our olfactory or retro-olfactory tracts? A terminological diversity, evoking the creative and yet unknown interpretation of taste. If the philosophical approaches of the "knowledge of drinking" give the impression of saying everything and the opposite, it is actually being done in order to awake and put in motion the taste buds, the tasting recollections and memory, as well as the principles of the sensory analyses. In addition, we are trying to define the good wine from an ethical point of view, the pleasure of our "onologism [19]", that is our personal relationship with wine. Hence the importance of words which awake the thoughts and the tasting (sensory) reflection as culinary (cultural) in order to be translated by a notion of knowledge related to oenology.

The wine is felt by the French nation as a good of their own, as well as their 360 types of cheese and their culture [20].

The personal experiences of each taster lead to different conclusions, such as "I love" or "I dislike", but could this be satisfying enough? It is common to think about a symbiosis between a peculiar wine and ourselves. Our general feeling at the end of a tasting may vary depending on our current condition, our mood or the way we feel. Of course, experience teaches us a lot about the wine. But a simple tasting, which is expected to make us discover, even most, to teach us something, frequently ends up in an over-generalization. To give only an example, the argumentation in terms of consent between dishes and wine, previously original and creative, concerning the "marriage" of foie gras and a liquorish wine, became nowadays a combination that is ordinary, limited and 
lacking any communicational interest.

In this frame, where the taste and the judgment are seen as subjective, so as neither to wrongly judge, nor to follow the opinion of others, we estimate that tolerance might be the solution when it comes to tastes and colors. But being systematically tolerant towards the tastes of others, doesn't eventually mean not to have an opinion and to confine ourselves to a void content exchange? In other words, who are we to judge the gustatory opinion of others? As such, the taster, who makes a qualitative judgment, is a priori an educated amateur, especially if his remark is constructive and is able to give new meanings to the representation of wine. In such cases, there are two alternatives: either to put aside the prejudices and accept the presented wine without comments, or to express our prejudices freely and reject without subtlety the wine or the olfaction that we do not agree with, without perceiving what they really represent. Having an intuition and then expressing a judgment, sometimes followed by a review about the wine, consists in judging a person by means of his wine production. Furthermore, there is an important share of identification in the act of judging a wine. This judgment is worth not for trying to see whether it corresponds to the qualitative and normative expectation of the wine, but in the attempt to understand the real nature of the analyzed wine. Consequently, we will understand that the subjective opinions and judgments are theoretically more capable of giving understanding to the taster, from an oenological point of view, rather than touching the self-esteem of the wine-producer.

Thinking the wine tasting in these terms means reflecting upon the report which exists between man, his environment and what makes him grow-up. The common feature of the opinions expressed by different humanistic sciences is that man is a taster and that this situation is at the same time natural and social for him. This situation makes him constantly return to the basic things, go back to the necessities of knowledge and of learning, in order to have control over what he drinks and tastes, without really knowing everything, with the purpose of giving his mind and spirit the possibility to think over the incorporation and create his own representations.

Thus, wine is among the most significant of all the sciences; among those contributing to the formation, expression and evolution of knowledge and thinking. Profoundly changed by each century, wine is definitely a point of reference for all the domains: philosophy [21], religion [22], politics [23], etc. Nevertheless, as selfconfident as we could be about the validity of this phenomenon, the evolution of the representations of "drinking" will only aspire to a real science title as long as theories regarding the knowledge of tasting will not be elaborated. Such potential theories could appear to us as only chimerical.

Nowadays it is necessary to elaborate a theory for the knowledge of tasting in a multidisciplinary and broad sense, in order to include not only notions related to the taste structure, to memory, to the analysis and its conclusions, to the way we drink wine and, above all, to the information it carries out. It should also take into consideration the psychological mechanisms which provide this information and the process of discursive exchanges that create a convivial tasting.

More important than the scientific notions, it is actually "the shape" of a thoughtful and argued tasting that we are trying to give value to. We are also trying to explain the logical connections between other domains of knowledge and other traditional procedures of incorporation.

It could be that, deeply, our "oenologism" is not to be found in the choice of wines, but in tasting and knowledge. This moment, made of good fellowship or familiar elements engaged in a rite which translates into conviviality and sharing, unites in a common spirit the exaggerated advocates of oenology "œenoliques [24]" or “œnomanes [25]”, the defenders of oenology “œnosophists [26]”, passionate oenologists "œnolâtres [27]”, wise oenologists “œnosophes"”, analytical oenologists “œnologiciens” and amateur oenologists “œnophiles"”.

No matter who are the members constituting this speaking time, that can be either hedonist, comparative or analytical, we are dealing with a moment when we try to better grasp the events, the discussions and the pleasures.

\section{Wine Argumentation Process: Transmitter and Receiver}

Each of us has different expectations from the organoleptic qualities of a wine, experienced during the process of tasting. The wine producer imagines an "intentional quality", while taking care of his vines. After vinification,

\footnotetext{
${ }^{2}$ The Knowledge of Wine. (In French l'œnosophie from the Greek Oeno Wine and Sophie Wisdom).

${ }^{3}$ Term Still Used, but Disappeared from the Dictionary between 1952 and 1962. (Raimbault, J.-C. (2006) Les disparus du XXe siècle, éditions du Temps, 400 p.)
} 
against the technical and climatic difficulties met, and depending on the wine vat blending, the wine producer rectifies his or her wine definition and shapes an "expected quality".

From the marketing viewpoint, a good wine is a wine which is well-sold. If we consider that wine quality has as a purpose to satisfy he who produced it, we are obviously no longer in a marketing perspective [28].

The customer, who reads the label in a supermarket row, or the wine menu in a restaurant, imagines a "perceived quality". After he or she tastes the wine, they define an "intermediate quality", also called "final quality", this until he or she pays the bill and realizes the "real quality" called sometimes "quality-price value".

During each of these four stages, prescribers use a different vocabulary, in order to justify the modifications/ changes of their estimation (Figure 1).

From an organoleptic viewpoint, what is good to drink will be visually appealing, with a pleasurable smell, touch and taste. The tasting must be pleasurable in order to say that a wine is good. In fact, endorsed by the "quality-price value" axis, the "organoleptic-tariff" evaluations involve each and every person's experience with wine. It is, in the end, a subjective approach. What is good to drink or taste will be different from one person to another. For example, during a wine tasting, it is rare that wine would be defined as good for all the participants, as some are naturally more sensitive [29] to some flavor (sweet) or smell (sulfur) which will affect their judgement of quality, and others more sensitive to the technical wine making, in order to understand "why a wine is good?” [30].

The wine representation varies depending on the illusion that the producer creates himself of his own production (back-office), of that he wishes to propose to the eyes of the consumer, and of that of the wine taster (front office).

The wine quality declines with the concept of "in" and "off". The quality of "in" is what you have in your glass of wine. But the new customer is ever more demanding at environmental protection level, health effects, respect for the biodiversity etc. It is the quality of "off" [31].

The diagram of gastronomical identity is constructed starting from the conscious or unconscious ingredient that is table history, of the individual and of his family: a gastronomic and oenological heritage [32] which adds to the physiological needs.

In order to distinguish this gastronomic identity and to give it coherence, throughout inner discovery, it is necessary to take into account the gastronomical context, such as the individual social level, connected to his food practices and representations. The wine and food history stored in the sensorial and sentimental memory underlines that, from immemorial times, the relationship to wine is influenced by the family environment, feeling and speech of the educational background. All these sensorial archives are intimately linked to the imaginary that, over the years, will give a personal definition to these ingredients. The imaginary has often modified the primary information in a wine representation not always attractive, or in a simulacrum of the reality. Beyond imagination, the present is defining the choice in terms of wine and food preferences, connected to the religious, ethnical, ethical dispositions, or even non rational ones.

Most of the definitions of food identity give place to imagination, at the same level as objective features. Yes, objectivity in terms of taste is highly controversial, because there is good only what we consider good at a given time, $\mathrm{T}$, and that is likely to become unsatisfactory for us tomorrow. The most important would be thus to take pleasure in this identity construction filled with fragrances, savories, textures, colors, impressions and pleasures...

\begin{tabular}{|c|c|c|c|}
\hline \multicolumn{2}{|c|}{ By the wine-producer (back-office) } & \multicolumn{2}{|c|}{ By the wine customer (front-office) } \\
\hline $\begin{array}{c}\text {-Before vinification- } \\
\text { Intended quality } \\
\text { or } \\
\text { Virtual quality } \\
\text { (All possible typicalities) }\end{array}$ & $\begin{array}{c}\text {-During vinification- } \\
\text { Expected quality } \\
\text { or } \\
\text { Potential quality } \\
\text { (Categorizing and selecting the }\end{array}$ & $\begin{array}{c}\text {-Before tasting - } \\
\text { Perceived quality } \\
\text { or } \\
\text { Current quality } \\
\text { (Formalizing the wine) }\end{array}$ & $\begin{array}{l}\text {-After tasting- } \\
\text { Real quality } \\
\text { or } \\
\text { Relativized quality } \\
\text { (Wine evaluation) }\end{array}$ \\
\hline $\begin{array}{l}\text { Employing encyclopedia } \\
\text { means of expression }\end{array}$ & Referential means of expression & $\begin{array}{l}\text { Formal means of } \\
\text { expression }\end{array}$ & $\begin{array}{c}\text { Criteria/standard means } \\
\text { of expression }\end{array}$ \\
\hline
\end{tabular}

Figure 1. Praxis of enunciation for the wine argumentation process. 


\section{The Construction of Wine Taster Identity}

A complex universe, fruit of the intelligence, allowing the wine soul to be protected, educated, receive focus or freedom. [33]

In order to initiate in the wine representations and speech resources that are attached to it, it is necessary to take into consideration, in terms of prevention, the sociological frame of wine, meaning to convey that wine, as an alcoholic drink, is a danger in itself, but, in an equal measure, a cultural element, an artisan work of art, and an instrument of social distinction, but also that wine is an aliment after all. But wine, in order to be sublimated in the speech act, is supported by a vocabulary with symbolic features [34], historical, sensorial, in connection to nature, environment, context and entourage [35].

Effectively, we speak here of face to face communication. This kind of vocabulary constantly makes reference to environment, in opposition to the global, impersonal and abstract characteristics of mass communication [36].

Concerning the pedagogical supports useful for the discursive paradigm of the good wine, "the regional paper press gives access to the representation universe specific to locally situated lecturers, and thus a series of clichés in effect in a region” [37], giving importance to the discourse focused on landscape and territory, while many classical writers approach the wine representation based on more poetical references, like Pierre de Ronsard, to give only an example.

At that time you thought that a divine force

Was in this plant and, digging its roots,

Carefully you made its savage grapes

The next year sweeten in good wines.

You wanted to go round the world, in order to

Teach humans how to use your wine.

Pierre de Ronsard [38]

In order to emphasize this aspect, we have selected a corpus of written papers for a "Primary school certificate”, collected from a school book from the 1940-1941 sessions, for the use of teachers, corresponding to what we call today "annals”. The examination proofs are incontestably from eight subjects from the obsolete universe of study certificates called "certif"4 in France. Let's not forget that the targeted audience (pupils/receivers) had the advantage of a discursive pedagogical support, connected to the everyday activities, from the barrel circumference to the rows of vines length, passing by a range of topics concerning that which gives rhythm to our everyday life: food. Thus, we have noticed on a corpus of 280 subject exercises, from the "General textbook for primary instruction $1940-1941$ ” that $23.21 \%$ of the exercises addressed the food topic, either for science lessons, economy, orthography, geography, dictation, writing skills or drawing lessons. We have noted, on the other side, that the biggest number of exercises included in the large chapter entitled "food" were also discussing wine (1/3), followed by topics like: agriculture, potatoes, corn, milk, alcohol, kitchen, water, oil, dining room, harvest, plate, bier, mushrooms, jam, water, crayfish, manure, epicurean, snail, flour, barrel, seed, chestnut, tablecloth, food, bread, fish, restaurant, table, vine.

The interest to appeal to a multidisciplinarity of supports, in order to discover the useful vocabulary of wine tasting, is that, beyond the cultural fact involved, our speech becomes an analytical meta-discursive or an interdiscursive approach adaptable in each situation and with all the tasting apparel.

Thus, "to taste" [39] allows the discovery of a personality feature through speech, as the words to communicate or to sell wine [40] allow to exchange, to awaken our creativity, imagine, anticipate, choose, make interpretations, on condition to not have any peremptory critical judgement.

Knowing how to drink is a national technique serving to qualify French people, to prove at the same time its performative power, its control and its sociability (Barthes, 1957).

The solutions that can be adapted to this transmission are to demand the experiencing, vary the communication

${ }^{4}$ Polemics Concerning Measuring Tools Used Ended up in Discrediting This Kind of Certification—That Was Officially Suppressed in 1989 Yet Which Has Longtime Results Sometimes Regrettable. 
methods, and to use an adaptive logic.

Introduced by the intermediary of communication approach, audio-oral or more recently, through action, the main objective is to produce coherent discourses concerning a real situation, integrating in a spontaneous speech the different useful language acquisitions. [41]

Interdisciplinary approach is a major asset in order to give value to wine speech, highlighting regional geography, the history of a region and the touristic places, the knowledge connected to intangible heritage [42], and in terms of individual perception, through the tasting rites and rituals.

The prescribers of the wine speech encoding, beyond wine producers, the wine sellers, the sommeliers, are also, indirectly, the researchers, academicians, professors and teachers, in geography [43], history [44], philoso$\mathrm{phy}^{5}$, anthropology or communication sciences [45], the partners for value giving (Bureau interprofessionnel du vin, wine guides, editors, etc.), and also, naturally, the entourage, family and friends. All these cultural actors, participating in the construction of the wine knowledge, have as a stake to highlight an interdisciplinary approach.

Yesterday, wine vocabulary was sustained by the regional orientation of the 1950's [46], by the hygiene of the stores and wine vats during the 1960-1970's [47], by the constant appeal to terroir during the 1980's ${ }^{6}$, by technology in the 1990's [48]. Today, "Wine heritagisation" [49] discourse has become the main trend, since the inscription of the gourmet French meal on the Representative List of Intangible Heritage (UNESCO). But what will it be like tomorrow? Will we base our wine arguments on artistic, scientific, political, economic features...?

While the advertising [50] about wine, before the Evin ${ }^{7}$ law, used sensuality and provocation in order to promote this product, during the 1990's and the 2000's the orientation is towards notions like conformity and heritagisation. Like "Voltaire [who] diferentiates between sensual taste and intellectual taste" [51], wine knew how to make evolve its paradigm and with it its vocabulary in order to get value, and along with it the customers' vision concerning the definition of a good wine.

While wine stands for an academic ${ }^{8}$, legal ${ }^{9}$, communitarian $^{10}$, international and official ${ }^{11}$ definition, it provides at the same time a symbolic imagery, of social representations, being also represented in the rows of supermarkets with all the economical significations attached.

\section{Wine Tasting as New Social Practice in Romania}

In the last few years we have noticed in Romania the practice of wine tasting by non-professionals, first in the context of advertising or marketing events. Professional wine-tasters are brought in front of non-initiated to talk about wine or make demonstrations, and neophytes have their part on the stage in the act of tasting and expressing their own opinions. The wine tasting allows the theatricality of a rite, involving body and gestures, emotions, feelings, as well as speech acts, communication. A sensorial, relational, cognitive pleasure, involving the knowledge of how to do, getting into contact with the connoisseurs, becoming a connoisseur. A double rite: of passage, from amateur to connoisseur, and of exchange with the convives involved in the wine tasting event. For the brands it is an occasion to become visible, while media are also interested in writing about these wine tasting events, representations, as they allow narrativity, a scenography, and characters. Cave visits became a practice open to tourists and visitors, offered by big wine producers such as Cotnari, Bolta Rece, Vinia, Bucium, etc. Even monasteries propose wine tasting rituals as part of their cave visits, as is the case of the liturgical or monastic wine, at Cetăţuia Monastery (Iași, Romania) [52].

Wine bars are also the occasion to display and share knowledge and experience the mise-en-scene of wine-tasting. These kind of locations became fashionable lately, if only we were to name places like Corks Cozy

\footnotetext{
${ }^{5}$ The module Philosophie du vin, DU Vin Culture et Enotourisme. University of Burgundy.

${ }^{6}$ Developing AOC.

${ }^{7}$ The Law of 10 January 1991, Concerning Fight against Smoking and Alcoholism.

${ }^{8}$ Dictionnaire Larousse Definition: 1-Fermeted Drink Prepared from Grapes or Fresh Grape Juice. 2-Name Given to All Juices Is Transformed to Alcohol by Fermenting (Rice Wine). 3-In the Eucharistic Rite, the Sacred Sign of Christ's Blood.

${ }^{9}$ In France, the Legal Definition of Wine Goes Back to the Law Griffe from the 14th of August 1889, Reserving This Denomination for: Exclusively Produced from Fresh Grape Fermenting or from Fresh Grape Juice.

${ }^{10}$ The Definition of Wine at Community Level has a New Codification Elaborated during the Council of the 17th of May 1999: Wine Is the Product Exclusively Obtained from Alcoholic Fermenting, Total or Partial, of Fresh Grapes, Crashed or Not, or of Grape Gravy.

${ }^{11}$ Official Definition of the International Organization of Vine and Wine: Wine Is Exclusively the Drink Resulted from Alcoholic Fermenting Complete or Partial of Fresh Grapes, Crashed or Not, Or of Grape Gravy. Its Acquired Alcoholic Strength Cannot Be Less than 8.5\% Vol.
} 
Bar, Bruno Wine Bar, Abel’s Wine Bar, Corelli, Beros \& Van Schaik, 1000 Visages (1000 de chipuri), Elvino (Tapas and Wine Bar), Experience Vinexpert, Ethic Wine, all showing that "wine tasting is the latest fad for going out” [53].

We have made non-participative observation in a wine bar in the historical center of Bucharest, called Dionysos (taste, take away, delivery). According to the owner, the clients are business men, foreigners in a good proportion, and he bases his relationship to the customers on discussions intended to conduct to new experiences:

If there is something I would reproach to wine, is the fact that it induces a kind of timorousness, of paralysis... a double effect: the relationship depends on how ready we are to understand wine, but also on its affordability.

Our clients now are quite different from those we had one year back, when we opened the wine-bar. We have in a way guided them, educated them, through the wine selection and sometimes friendly discussions. We do not sell a Brunello wine, but a certain Brunello wine. I want the customers' experience in our bar to be such that he or she will come back. My concern is not quality versus price value, this is the issue of a supermarket. My concern is to offer an experience! $!^{12}$

But what is the definition of the good wine for a Romanian wine consumer? We have realized interviews with consumers who appreciate, understand and consume wines, either socially or individually:

Good wine is for me... a surprise. During communism, in Romania, good wine was a mere utopia, only few privileged people had access to good wine, hence the wine consumers' 'understanding and knowledge of what means a good wine were lost for a few generations. Only after 1989, or even later, we started to make a distinction between the good wine and the bad wine, the so-called "vin de surcele" ("wine made of kindling"). Romania entered slowly among the countries who produced good wines, for example Hungary or even Bulgaria are way ahead of us. Good wine means for me-although I believe it to be paradigmatic for non-professional wine-tasters - a wine that satisfies our entire capacity to participate in the ceremonial of wine consuming, from taste, flavor, fluidity, color, and all that means the immediate appearance of a wine in a glass. [...] If I were to synthesize all my relationship to wine, I would say Fetească Neagră. ${ }^{13}$

Beyond everything wine is about being together, sharing a moment in life, but also experiencing its possibilities of taking our mind, feelings and imagination to a different realm:

The meeting with wine depends upon circumstances. It is a complex meeting, and, if you are not ready, it may become complicated. Wine needs time and attention to be discovered. It has color, flavor, sometimes it is severe, sometimes it is soft and velvet-like. There are heavy and deep wines, and friendly wines, you can feel them dance in your mouth. Wine has in it a certain magic, it is invoked as a substitute of the Divine blood. It is a drink with astronomic and soil memory. Good wine comes in many shapes, as good people come. Normally, you don't drink alone: wine is an occasion for conviviality. Wine is about communication. Wine needs to be charmed, with words. The level of the dialogue with the wine depends on the observation and attention power, but also on the partner you share the table with. ${ }^{14}$

\section{Conclusions}

From the unexpected olfactory notes, to the honest smile of the amateur, from the banana flavor of the Beaujolais new wine a hundred times passed over, pale argument today, to the wine technique never before revealed, offered as a gift, the common point is maybe the relationship to the other. Because we only "nurture" words and products that we appreciate, for the interest that we invest in them, and for the reciprocation of our interest. Major wine producers, important sommeliers, excellent professors or great parents, all are able of knowledge transmission, having thus their secret to share, more or less voluntarily, sometimes with errors, sometimes with lapses, sometimes on a sentimental note.

The interdiscursivity [54] approach concerning this product allows a (re)signification of the representations of

\footnotetext{
${ }^{12}$ Personal Interviews with Radu Tudor, Owner of Wine Bar, and with George Bălan, Partner in Administrating a Wine Bar in Bucharest, January 2016.

${ }^{13}$ Personal Interview with Pavel Șuşară, Romanian Artist Critic, February 2016.

${ }^{14}$ Personal Interview with Vlad Ciobanu, Romanian Artist, February 2016.
} 
the wine values. The approach concerning the formalizing of a "good wine" is framed by such elements as wine and product, social purpose, either on a long-term perspective or as a transitory purpose, environment, context and their limitations, in other terms the common territory between man and product constituted by the experiential structure; as the tasting procedure, beyond being a knowledge is an incorporation experience that shares a part of each person's identity.

\section{References}

[1] Leroyer, P. and Gouws, R. (2009) Terms Related to the Wine: Lexicographication of the Online Wine Tourism. French Magazine of Applied Linguistics, XIV, 99-116.

[2] Gautier, L. and Lavric, E. (2015) Unity and Diversity in the Discourse about Wine in Europe. Document of the Conference in Innsbruck, Peter Lang, 220 p.

[3] Pertuiset, G. (1995) La dégustation des vins, coll. Philosopher, Quintette, 71 p.

[4] Poulain, J.-P. (2001) Manger aujourd’hui: Attitudes, normes et pratiques. Privat, Paris, 246 p.

[5] Ibekwe-Sanjuan, F. (2012) La science de l'information: Origines, théories et paradigmes. Lavoisier, p. 115.

[6] Lenoir, J. (1981) Le nez du vin: les arômes banane, cannelle, cassis, cerise, civette, framboise, pin, poivron vert, réglisse, truffe, vanille, violette. Ed. Jean Lenoir, Paris.

[7] Lenoir, F. (2013) Du bonheur: Un voyage philosophique. Fayard, Paris, p. 91.

[8] Ollivier, B. (2007) Les sciences de la communication: Théories et acquis. Armand Colin, Paris, p. 210.

[9] Franjus-Adenis, N. (2016) Qu'est-ce qu’un discours de dégustateur professionnel? In: Parizot, A. and Stengel, K., Eds., Noms de plats et écrits culinaires: Quand les mots se mettent à table, coll. Questions alimentaires et gastronomiques, L'Harmattan, 401.

[10] Bonescu, M., Brouard, J., Boutaud, J.-J., Caseau, C., Sutan, A. and Tavilla, V. (2016) Le Vin du futur: De la convention à la création. In: Stengel, K. and Boutaud, J.-J., Eds., Cuisine du future et Alimentation de demain, coll. Questions alimentaires et gastronomies, L'Harmattan, p. 139.

[11] Bougnoux, D. (2013) La communication par la bande: Introduction aux sciences de l'information et de la communication. La Découverte, Paris, p. 21.

[12] Collectif (1844) Dictionnaire des sciences philosophiques, Vol. 1. Hachette, Paris, p. 573.

[13] Peynaud, E. and Blouin, J. (2013) Le goût du vin—Le grand livre de la dégustation. 5e éd, Dunod, Paris, p. 3.

[14] Anonyme (1938) Bulletin international du vin, Vol. 11, No. 2, p. 33.

[15] Goffman, E. (1991) Les Cadres de l’expérience. In: Joseph, I., Dartevelle, M. and Joseph, P., Eds., Le sens commun, Editions de Minuit, Paris, 576 p.

[16] Stengel, K. (2015) La dégustation du vin: Un acte expérientiel et identitaire entre théâtralisation et culturalisation. In review Lexia No. 19 Alimentation et identité culturelle, Aracne Editrice, Rome.

[17] Marcellini, A. and Miliani, M. (2005) Lecture de Goffman. In Corps et culture No. 4, 1999, mis en ligne le 25 janvier 2005, Consulté le 12 Décembre 2014. http://corpsetculture.revues.org/641

[18] Proust, M. (1914) Du côté de chez Swann: A la recherche du temps perdu. Grasset, Paris, 537 p.

[19] Not to be confused with “alcoholization: chronic alcoholism”, term appeared in 1972 (Raimbault, J.-C. (2006) Les disparus du XX $\mathrm{XX}^{\mathrm{e}}$ siècle. Éditions du Temps, 400 p).

[20] Barthes, R. (1957) Mythologies. Seuil, 98.

[21] Raspiengas, J.-C. (2011) Le vin, école de philosophie. La Croix, le 2 Septembre 2011.

[22] Bouvier, M. (2009) Le vin, c’est toute une histoire. Jean-Paul Rocher éditeur, Paris, 145 p.

[23] Maillard, J., De Costa, O. and Smith, A. (2007) Vin et politique. Presses de Sciences Po, Paris, 384 p.

[24] Dorvault, F.-L.-M. (1844) Person Having Wine as Excipient L’Officine. ou Répertoire général de pharmacie pratique, p. 120, Term Disappeared in 1972. (Raimbault 2006)

[25] Delamare, J. and Delamare, F. (1958) People under the Yoke of Oenomania Severe Alcoholic Delirium. In: Garnier, M. and Delamare, J., Eds., Dictionnaire illustré des termes de médecine, Maloine. Term Disappeared from the Robert dictionary in 1952, Not to Be Confused with Oenomacie Which Means Wine Divination.

[26] People Using Wine to Philosophate. Term Related to Knowledge of Gastronomy.

[27] De Rivarol, A. (1827) Formed with the Prefix Oeno for Wine and the Suffix Latre for Adoration. Just like a Gourmand Person for Food, a Gourmand for Wine Person Is Somebody who Worships Their Stomach [Like with Wine] Diction- 
naire classique de la langue française, Term disappeared in 1952.

[28] Hauteville, F. (2009) Comment inspirer le bon dans le marketing? In: Le vin est-il bon?, université de la vigne et du vin, p.68.

[29] Stengel, K. (2015) Quand le bon ne rend pas insensible: du bon et de ses rapports avec le sensoriel, conceptuel, relationnel, expérientiel. In: Boutaud, J.-J., Eds., Sensible et communication: du cognitif au symbolique, ISTE éditions, Londres, 81.

[30] Abbal, P.H. and Coulon, P. (2014) Pourquoi un vin est-il bon? France Agricole Editions, Paris, 338 p.

[31] Torrès, P. (2009) Le nouveau plaisir du vin. In: Le vin est-il bon? université de la vigne et du vin, 111.

[32] Stengel, K., (2014) Hérédités alimentaires et identité gastronomique: Suis-je réellement ce que je mange? Coll. Questions alimentaires et gastronomiques, L’Harmattan, Paris, $122 \mathrm{p}$.

[33] Pitte, J.-P. (2013) La Bouteille de vin: histoire d’une révolution. Tallandier, Paris, 13. http://dx.doi.org/10.3917/talla.pitte.2013.01

[34] Reckinger, R. (2013) Parler Vin: Entre normes et appropriations. Coll. Tables des Hommes, PUR-PUFR, 386 p.

[35] Coutier, M. (2007) Dictionnaire de la langue du vin. CNRS éditions, Paris, 476 p.

[36] Thibault-Maulan, A.-M. (1975) Les impasses de la communication. centre d'étude et de promotion de la lectureéditions Retz, Communication et langages, 25, 16.

[37] Versel, M. and Laügt, O. (2006) Du vin au corps, mots de fête. In: Revue Média et information—Le corps, le vin \& les images, No. 23, L’Harmattan, Paris, 97.

[38] Ronsard, P. De (2013) L’invention du vin. In: Kilien, S., Eds., De Ponchon à Béranger: Poésies du vin, L\&C éditions, Paris, 44.

[39] Peynaud, E. (1980) Le goût du vin. Dunod, Paris, 237 p.

[40] Gilbert, D. and Compan, C. (1998) Les mots qui font vendre le plus et beaucoup mieux. Coll. Les clés de la réussite, Egico, 216 p.

[41] Chollet-Mocanu, C. (2011) L'enseignement des langues romanes et de l'anglais dans un lycée roumain: analyse des manuels scolaires et pratiques pédagogiques. Thèse de doctorat en Sciences du langage, École doctorale Culture et Patrimoine, Université d'Avignon, 55.

[42] Ory, P. (1998) Le discours gastronomique français des origines à nos jours. Gallimard, Paris, 203 p.

[43] Pitte, J.-R. (2009) Le désir du vin à la conquête du monde. Fayard, Paris, 333 p.

[44] Boulay, T.H. (2014) Food \& History, Vol. 11, 414 p.

[45] Boutaud, J.-J. (2005) Le sens gourmand. De la commensalité du goût et des aliments, Jean-Paul Rocher éditeur, Paris, $200 \mathrm{p}$.

[46] Sailland, M.-E. (dit Curnonsky) (1953) Cuisine et Vins de France, Larousse.

[47] Orizet, L. (1961) Le vin. Hachette, Paris, 22.

[48] Bellard, J. (1998) Paroles de vignerons \& vigneronnes d'Anjou et de Saumur. Cheminements, 50.

[49] The Inscribing Process, by UNESCO, of the French Tradition of Terroir Wines on the Representative List of Intangible Cultural Heritage of Humanity. http://www.sommelier-france.org/images/stories/pdf/vinterroir_unesco.pdf

[50] Berthelot-Guiet, K. (1993) Les mots pour le dire et le vendre, le langage publicitaire facteur et vecteur de néologie. Diplôme d’Études Approfondies en Sciences de l’Information et de la Communication, Université Paris IV Sorbonne, CELSA, 2-3.

[51] Boutaud, J.-J. (dir.) (1997) Cultures, Nourriture. No.7, Internationale de l’Imaginaire, Babel, 51-59.

[52] Marinescu, A.H. (2013) Médiation du savoir-vivre et civilisation monastique roumaine: la dégustation des vins. In: Panaitescu, C. and Foșalău, L.C., Eds., Vigne, vin et ordre monastiques en Europe. Une longue histoire, Chaire UNESCO Culture et Traditions du Vin, Dycolore Groupe, Dijon, 73-85.

[53] Unde ieșim. Wine bars în București-ultima fitză în materie de ieșit. Metropotam, 12 April 2013. http://metropotam.ro/Unde-iesim/Wine-bars-in-Bucuresti-ultima-fitza-in-materie-de-iesit-art8787829757/

[54] Stengel, K. (2015) L’interdiscours dans la dégustation: Une (re) signification des représentations du vocabulaire du vin. In: dir. Bogdan, C., Walter, J. and Béatrice, F., Eds., Patrimoine, création, culture à l'intersection des dispositifs et des publics, Coll. Communication et civilisation, Éditions L’Harmattan, Paris, 122. 